\title{
A memória como procedimento ficcional no conto "El Árbol” De María Luisa Bombal
}

\section{Memory as a fictional procedure in the short story “El Árbol” By Maria Luisa Bombal}

Tatiane Lazaro de Oliveira ${ }^{1}$ Deolinda de Jesus Freire ${ }^{2}$

Recebido em: $30 / 08 / 2020$

Aprovado em: 14/10/2020

Publicado em: 20/12/2020

RESUMO: Este artigo propõe uma leitura crítica do conto "El Árbol" da escritora chilena Maria Luisa Bombal, publicado em 1940, considerando a memória como procedimento de construção ficcional. A narrativa apresenta como personagem principal a jovem Brígida, filha mais nova de seis irmãs que foram educadas apenas pelo pai. Na narrativa, Brígida representa o típico papel atribuído à figura feminina no início do século XX, constantemente submetida à figura masculina, primeiro à do pai e, após o casamento, à do marido. A partir do procedimento ficcional de construção da memória, interessa-nos analisar como o leitor é apresentado às angústias de Brígida desde a infância e como esses sentimentos vão se intensificando com o visível fracasso de seus anseios femininos. Consideramos que esses anseios representam a forma como a mulher era vista pela sociedade patriarcal no início do século XX e como os resquícios dessa imagem ainda reverberam, de forma diversa, na contemporaneidade do século XXI. Como base teórica do conto, consideramos estudos de Alfredo Bosi, Ricardo Piglia e Edgar Allan Poe. Para reflexões sobre a memória e sua construção ficcional, apoiamo-nos em Ecléa Bosi e Walter Benjamin.

Palavras Chaves: Estudos Literários; Literatura Hispano- Americana; Conto; Memória; Maria Luisa Bombal.

ABSTRACT: This article proposes a critical reading of the short story "El Árbol" by the Chilean writer Maria Luisa Bombal, published in 1940, considering memory as a fictional construction procedure. The narrative presents Brígida as the main character, the youngest of six sisters who were raised solely by their father. In the narrative, Brígida represents the typical role assigned to the female figure at the beginning of the 20th century, constantly subjugated to the male figure, first to the father and, after marriage, to the husband. Based on the fictional procedure of memory construction, we are interested in analyzing how the reader is introduced to Brígida's anxieties since her childhood and how these feelings are intensified by the visible failure to fulfil her female yearnings. We consider that these yearnings represent the way women were seen and defined by the patriarchal society at the beginning of the 20th century, and that the vestiges of this image still reverberate, in a different way, in the contemporary 21st century. As theoretical basis for the short story genre, we considered studies by Alfredo Bosi, Ricardo Piglia and Edgar Allan Poe. To reflect on memory and its fictional construction, we relied on Ecléa Bosi and Walter Benjamin.

Keywords: Literary Studies; Hispanic-American literature; Short story; Memory; Maria Luisa Bombal.

1. Graduada em Licenciatura em Letras - Português e Espanhol pela Universidade Federal do Triângulo Mineiro.ORCID: 0000-0002-5742-7705 E-mail: tathy25@gmail.com

2. Doutora pela Universidade de São Paulo em Literatura Hispano-Americana. Professora com dedicação exclusiva da Universidade Federal do Triângulo Mineiro, em Uberaba-MG. Departamento do Letras. ORCID: 0000-0001-7372-9044 E-mail: deofreire@uol.com.br 
OLIVEIRA,T.L.;FREIRE,D.J.

\section{INTRODUÇÃO}

O conto "El Árbol” foi publicado em 1940, no Chile, após María Luisa Bombal ${ }^{1}$ regressar do exílio vivido nos Estados Unidos da América. A narrativa apresenta como personagem principal a jovem Brígida, filha mais nova de uma família em que o pai tem como obrigação educar, sozinho, as seis filhas. Brígida desempenha o típico papel atribuído à mulher no início do século XX, pois, com frequência, se vê submetida à figura masculina, principalmente ao pai e, após o casamento, por extensão, ao marido. Ademais, a construção da personagem evidencia os anseios impostos à mulher de sua época, ou seja, casar-se, constituir família e ter filhos. A história, narrada com base nas lembranças de Brígida, apresenta um narrador empenhado em compartilhar com o leitor as experiências da protagonista com o casamento e com a maternidade, ambas fracassadas.

Este artigo propõe uma leitura crítica do conto "El Árbol" tendo a memória como principal procedimento de construção da narrativa ficcional, cujo enredo e narrador são construídos a partir das lembranças fragmentadas de Brígida. Com a leitura da memória, interessa-nos analisar como o leitor é apresentado às angústias da personagem desde a infância e como esses sentimentos vão se intensificando com o visível fracasso de seus anseios femininos. Consideramos que esses anseios contribuem para representar, de forma ficcional, como a mulher era vista pela sociedade patriarcal no início do século XX.

\section{O conto e a situação exemplar}

A forma como o enredo é apresentado ao leitor no conto "El Árbol", a partir de lembranças, revela a relação dramática de Brígida com o seu passado, que, mesmo distante, se entrelaça com um passado mais recente. Essa relação elide o tempo presente, quase não narrado, pois o que interessa é o resultado de uma série de situações chaves que culminaram em uma atitude revolucionária para a época: a ruptura do casamento. 0 rompimento exigiu de Brígida um constante mergulho em suas memórias e é através delas que a personagem reflete e amadurece os fatos para, assim, poder enxergar e compreender a insatisfação e a infelicidade vividas em seu matrimônio.

A personagem Brígida é apresentada ao leitor a partir de lugares-comuns sociais que estabelecem o papel feminino na vida conjugal, principalmente o da mulher submissa e

\footnotetext{
${ }^{1}$ Nas obras completas de Maria Luisa Bombal, publicada em 1996, com introdução de Lucía Guerra, o leitor pode conhecer um pouco mais da vida dessa escritora chilena. Os relatos apresentados evidenciam uma vida pessoal conturbada, com escândalos e tentativas frustradas de homicídio contra a vida de Eulogio Sánchez, seu amor de adolescência. Bombal teve problemas com alcoolismo e, quando jovem, estudou na França e morou nos Estados Unidos devido ao exílio. Em 1944, casou-se com Saint Phalle, um nobre francês, com quem teve uma filha, Brigitte. O estilo literário de Bombal é considerado uma das influências para a obra de Juan Rulfo, tendo sido amiga próxima de Pablo Neruda e admirada por Jorge Luis Borges. Em seu fazer literário, a escritora introduziu questões sobre o universo feminino e o papel desempenhado pela mulher na sociedade, ainda que afirmasse não ser feminista.
}

Revista do SELL, Uberaba/MG (online) - V. 9 n. 2, p. 278-297, jul./dez. - 2020. 
OLIVEIRA,T.L.;FREIRE,D.J.

conformada em ser a esposa exemplar. A narrativa é conduzida a partir de flashes da memória da época da adolescência da personagem mesclados às situações vividas recentemente, já na fase adulta. Este movimento circular entre o passado e o presente são responsáveis por destacar a enunciação do conto. Como adverte Alfredo Bosi (2004), o convívio da consciência com a memória do passado de maneira intimista faz as personagens despertarem para a necessidade de ruptura e buscarem por seus verdadeiros anseios. Essa busca, para Brígida, desaguou, de certa forma, na fratura de seu casamento.

Os conflitos existentes no relacionamento conjugal de Brígida e Luis são determinantes para configurar a invenção temática da narrativa, pois o conto possui um lugar privilegiado em relação aos outros gêneros devido à liberdade para explorar 'situações' exemplares que são vividas pelo homem contemporâneo. Como destaca Bosi:

Repito a palavra-chave: situações. Se o romance é um trançado de eventos, o conto tende a cumprir-se na visada intensa de uma situação, real ou imaginária, para a qual convergem signos de pessoas e de ações e um discurso que os amarra. (2004, p. 8).

Bosi (2004, p.9-10) ainda pondera que alguns contos forjam uma relação dramática com o passado para ressaltar as marcas da posse e da perda. Afinal, o convívio da consciência com a memória produz certo intimismo de situações novas, algumas delas instigantes e revolucionárias. Assim, ao contista cabe explorar uma hora intensa e aguda da percepção do passado na narrativa ficcional. Tal percepção pode reunir os problemas e as lesões comportadas por uma sociedade, como a vida conjugal de um casal ou a violência e a exploração do homem pelo homem. No conto "El Árbol", a situação intensa revela-se a partir da ruptura de uma união, aparentemente sem amor, e conduz ao despertar da personagem Brígida, que se nega a continuar casada por formalidade e obrigação social. Portanto, o conto, como gênero, "cumpre a seu modo o destino da ficção contemporânea. Posto entre as exigências da narração realista, os apelos da fantasia e as seduções do jogo verbal, ele tem assumido formas de surpreendente variedade" (BOSI, 2004, p.7). Essas variedades dividem-se entre a representação do cotidiano burguês e das questões da vida urbana, podendo também aproximar-se de um documento quase-folclórico.

A situação exemplar vivida pela personagem, indício do momento singular do conto, deve despertar e instigar algum efeito de sentido durante a leitura. Edgar Allan Poe ressalta a relevância do efeito derivado da unidade de impressão que a leitura 'de uma só vez' deve provocar no leitor:

Se alguma composição literária é longa demais para ser lida de uma só vez, temos que concordar em abrir mão do efeito imensamente importante que deriva de uma unidade de impressão - pois, se forem necessários dois momentos de leitura, os assuntos do mundo interferem e qualquer intenção de totalidade é destruída na mesma hora (2011, p. 20).

Revista do SELL, Uberaba/MG (online) - V. 9 n. 2, p. 278-297, jul./dez. - 2020. 
Para atingir tal efeito, é fundamental ler o conto de uma só 'assentada'. Assim, a brevidade deve ser bem dosada pelo contista, pois a narrativa não pode ser nem curta nem longa demais. Sobre essa brevidade, Walter Benjamin (1993, p.9) afirma que, com o decorrer dos anos, o homem conseguiu abreviar até a narrativa. Para o filósofo, o homem contemporâneo não consegue cultivar aquilo que não pode ser abreviado, esse é um dos aspectos do conto (short story) e é o que também determina sua modernidade.

\title{
A narrativa circular: a música e o tempo
}

O tempo e a sequência de ações no conto "El Árbol" não são cronológicos, pois o enredo se inicia pelo final da história, mais precisamente com a personagem Brígida em um recital de música clássica imersa em lembranças do passado e já separada de seu esposo. O leitor é conduzido em um sentido inverso do esperado tradicionalmente, uma vez que o início já anuncia de forma abrupta o fim do casamento de Brígida e Luis. A estrutura da narrativa, metaforicamente, é construída a partir das estações do ano, que, por sua vez, estão atreladas às composições clássicas de Mozart, Chopin e Beethoven. ${ }^{2}$ Assim, as estações marcam, de forma cíclica, o tempo do casamento de Brígida e Luis.

Nas primeiras linhas do conto, Brígida assiste a um concerto de música clássica, que marca o presente da narrativa, ou seja, a enunciação. Ao ouvir Mozart, as lembranças da personagem são acessadas de forma involuntária e a conduzem para a infância:

\begin{abstract}
"Mozart, tal vez" - piensa Brígida. Como de costumbre se ha olvidado de pedir el programa -. "Mozart, tal vez, o Scarlatti...". ¡Sabía tan poca música! Y no era porque no tuviese oído ni afición. De niña fue ella quien reclamó lecciones de piano, nadie necesitó imponérselas, como a sus hermanas. Sus hermanas, sin embargo, tocaban ahora correctamente y descifraban a primera vista, en tanto que ella... Ella había abandonado los estudios al año de iniciarlos. (BOMBAL, 1996, p. 209).
\end{abstract}

O narrador evidencia seu papel onisciente na narrativa por demonstrar conhecer intimamente a personagem, inclusive como ela pensa e se sente: "piensa Brígida", "sabía tan poca música". Em outros momentos, deixa transparecer sua opinião a respeito da personagem - "Como de costumbre se ha olvidado de pedir el programa"3 -, construindo a imagem de Brígida como dispersa e com pouco conhecimento de música clássica quando comparada às irmãs. Uma das razões para esse comportamento é o fato de ela ter sido subestimada e preterida pelo pai durante a infância e depois pelo marido. Ao longo da

\footnotetext{
${ }^{2}$ No ensaio “El vals de enajenación: la alteridad trágica en 'El Árbol' de María Luisa Bombal”, de Tatiana Calderón Le Jollif, é comentada a presença da música clássica no conto, principalmente como se dá o ritmo ternário e circular da narrativa. Ademais, Le Jollif especifica como o ritmo de cada compositor envolve a personagem Brígida na narrativa.

3 Todos os grifos nas citações do conto "El Árbol" são de nossa autoria.
} 
OLIVEIRA,T.L.;FREIRE,D.J.

narrativa, o leitor percebe que essa dispersão atribuída à Brígida se repete, insistentemente, mesmo depois da separação.

A música clássica é um dos elementos que contribui de forma decisiva para a construção circular e cíclica da narrativa, pois representa o dispositivo desencadeador das lembranças da personagem. Assim, a estrutura é construída a partir do entrelaçar das memórias de Brígida. O narrador, ao nos contar sua história, principalmente o final de seu casamento, mescla o momento presente com memórias do passado mais distante, e também recente, como comprova o fragmento:

Y Mozart la lleva, en efecto. La lleva por un puente suspendido sobre un agua cristalina que corre en un lecho de arena rosada. Ella está vestida de blanco, con un quitasol de encaje, complicado y fino como una telaraña, abierto sobre el hombro.

- Estás cada día más joven, Brígida. Ayer encontré a tu marido, a tu ex marido, quiero decir. Tiene todo el pelo blanco.

Pero ella no contesta, no se detiene, sigue cruzando el puente que Mozart le ha tendido hacia el jardín de sus años juveniles. (BOMBAL, 1996, p.210).

Nesses fragmentos, temos a primeira referência à música clássica com Mozart, que, na sequência, terá como companhia Chopin e Beethoven. Mozart tem como função levar Brígida ao passado, ativando sua memória, afinal, não é a música que a leva, mas sim o próprio compositor. Com o uso da metonímia, cria-se a intimidade necessária para olhar o passado, pois os nomes são mencionados ao invés da obra executada: "Mozart la lleva, en efecto", "el puente que Mozart le ha tendido". O emprego da metonímia consiste em provocar um efeito de sentido, que seria a proximidade e intimidade de Brígida com as composições ou com os próprios autores. Essa intimidade guia o leitor para a memória e o passado da personagem.

Nessa perspectiva, os compositores não são apenas íntimos e próximos de Brígida, mas são os responsáveis por conduzi-la ao passado: "sigue cruzando el puente que Mozart le ha tendido hacia el jardín de sus años juveniles". Mozart é quem a leva aos anos juvenis porque sabe por onde conduzir a personagem, como se a conhecesse intimamente, inclusive a jornada que ela trilhou, levando-a para o próprio passado. A música é decisiva para acessar as memórias da infância de Brígida e trazer à tona o afeto e a inocência de sua juventude, quando ainda não haviam ilusões violadas pela decepção que o matrimônio Ihe causara. O efeito de sentido permite a construção da intimidade, afinal o envolvimento de Brígida com a música clássica permeou muitos momentos de sua vida.

O narrador nos mostra, ao mergulhar nas memórias de infância de Brígida, seu questionamento presente sobre o casamento com Luis. Ela conclui que somente ele poderia tê-la aceitado como de fato era: tonta, brincalhona e preguiçosa. Após ser levada a essas reflexões por Mozart, suas memórias são interrompidas, ainda pela música, agora,

Revista do SELL, Uberaba/MG (online) - V. 9 n. 2, p. 278-297, jul./dez. - 2020. 
OLIVEIRA,T.L.;FREIRE,D.J.

entretanto, com um acorde doce e firme que a conduz bruscamente de volta à sala de concertos, cessando suas lembranças:

Pero he aquí que Mozart la toma nerviosamente de la mano y, arrastrándola en un ritmo segundo a segundo más apremiante, la obliga a cruzar el jardín en sentido inverso, a retomar el puente en una carrera que es casi huida. Y luego de haberla despojado del quitasol y de la falda transparente, le cierra la puerta de su pasado con un acorde dulce y firme a la vez, y la deja en una sala de conciertos, vestida de negro, aplaudiendo maquinalmente en tanto crece la llama de las luces artificiales. (BOMBAL, 1996, p. 211).

Ao regressar de suas lembranças, Brígida retorna à sala de concertos, quando o narrador conta ao leitor que ela estava “vestida de negro". Sua vestimenta representa a sobriedade, introspecção e reflexão de seu presente frente a um doloroso passado. $\mathrm{Na}$ sequência, ela é novamente levada, agora por Beethoven, de volta para suas memórias. De forma cíclica, Brígida se lembra do início de seu matrimônio, época marcada pela primavera: " $Y$ ahora Beethoven empieza a remover el oleaje tibio de sus notas bajo una luna de primavera. ¡Qué lejos se ha retirado el mar!'. (BOMBAL, 1996, p. 211). A primavera ao som de Beethoven reafirma o momento mágico e intenso do passado revisitado, que representa o sonho das mulheres de sua época: o casamento. A primavera é uma estação marcada pelo florescimento, simbolizando renovação, o que reforça as expectativas e as ilusões da personagem com relação ao matrimônio. Os elementos se entrelaçam pela memória na construção dessa nova fase na vida de Brígida.

O narrador acessa as memórias da jovem e narra com detalhes seu primeiro ano de casada, descrevendo vários momentos em que ela tenta se manter próxima de seu esposo, no entanto, ele insiste em manter distância. Os desejos de Brígida são típicos de uma jovem recém casada de sua classe social: viajar, conhecer a Europa, ver a neve. Entretanto, os planos não saem da forma esperada pela jovem:

Llegó el verano, su primer verano de casada. Nuevas ocupaciones impidieron a Luis ofrecerle el viaje prometido.

- Brígida, el calor va a ser tremendo este verano en Buenos Aires. ¿Por qué no te vas a la estancia con tu padre?

- ¿Sola?

- Yo iría a verte todas las semanas, de sábado a lunes.

(BOMBAL, 1996, p.214).

O verão, estação marcada pela chuva constante e calor excessivo, é a época do ano em que Luis promete levar Brígida à Europa para ver a neve, mas ele deixa de cumprir a promessa por conta de seus compromissos. Na narrativa, é quando surgem as primeiras frustrações de Brígida em relação ao seu casamento, fazendo com que ela deixe de ser tão passiva e comece a questionar se realmente é feliz. Nesse momento, Chopin surge para marcar a chegada das chuvas:

Revista do SELL, Uberaba/MG (online) - V. 9 n. 2, p. 278-297, jul./dez. - 2020. 
Chopin y la lluvia que resbala por las hojas del gomero con ruido de cascada secreta, y parece empapar hasta las rosas de las cretonas, se entremezclan en su agitada nostalgia.

¿Qué hacer en verano cuando llueve tanto? ¿Quedarse el día entero en el cuarto fingiendo una convalecencia o una tristeza? (BOMBAL, 1996, p.216).

A música de Chopin embala Brígida em uma fase um tanto melancólica, pois a personagem está ciente de sua insatisfação com o casamento e inicia um processo de reclusão, ficando mais isolada em seu quarto de vestir. $E$ devido às chuvas intensas $e$ constantes, a personagem se vê impossibilitada de sair, o que colabora de forma 'quase' natural para seu isolamento. Esses fatores só aumentam o tédio e a tristeza de Brígida.

Dessa forma, os compositores e as estações contribuem para a percepção de circularidade do tempo da narrativa, afinal são as estações da natureza que delimitam o período em que Brígida esteve casada, em torno de um ano. As composições de Chopin, Beethoven e Mozart, além do movimento cíclico, compõem o pano de fundo para as emoções da personagem.

A última estação mencionada é o outono, logo, subentende-se que o momento presente de Brígida, o da enunciação da narrativa, seja o inverno. O outono é a estação que tem como característica principal o desfolhar, o vento forte e a coloração dourada das folhas. É nessa época que as árvores se despem de toda sua folhagem para poderem nascer novas, como comprova o olhar atento do narrador:

$Y$ vino el otoño. Las hojas secas revoloteaban un instante antes de rodar sobre el césped del estrecho jardín, sobre la acera de la calle en pendiente. Las hojas se desprendían y caían... La cima del gomero permanecía verde, pero por debajo el árbol enrojecía, se ensombrecía como el forro gastado de una suntuosa capa de baile. Y el cuarto parecía ahora sumido en una copa de oro triste. (BOMBAL, 1996, p. 219).

O outono marca o momento em que Brígida se conforma com seu casamento e, mesmo não estando feliz, acredita que "la verdadera felicidad esté en la convicción de que se ha perdido irremediablemente la felicidad" (BOMBAL, 1996, p. 219). Assim, ela se despe de suas ilusões matrimoniais, assim como a árvore de suas folhas, e decide continuar sendo a esposa de Luis, mas sem entusiasmo e sem ira, apenas indiferente e gélida.

Brígida desperta dessa sensação de vazio com um som estrondoso quando a árvore, el gomero, é derrubada de uma só vez. Nesse momento, a fala da personagem se confunde com a do narrador, pois ambos sabem o que acontece. A personagem começa a despertar para a realidade decepcionante de seu casamento, mas, de forma confusa, mistura o passado recente, o corte da árvore, com seu tempo presente na sala do concerto:

Un estruendo feroz, luego una llamarada blanca que la echa hacia atrás toda temblorosa.

¿Es el entreacto? No. Es el gomero, ella lo sabe.

Lo habían abatido de un solo hachazo.

Revista do SELL, Uberaba/MG (online) - V. 9 n. 2, p. 278-297, jul./dez. - 2020. 


\section{(...)}

Encandilada se ha llevado las manos a los ojos. Cuando recobra la vista se incorpora y mira a su alrededor. ¿Qué mira?

¿La sala de conciertos bruscamente iluminada, la gente que se dispersa?

No. Ha quedado aprisionada en las redes de su pasado, no puede salir del cuarto de vestir. De su cuarto de vestir invadido por una luz blanca aterradora. (BOMBAL,1996, p.219).

Brígida reluta em voltar ao presente, pois ficou muito tempo presa ao passado, principalmente ao gomero, símbolo de sustentação de seu casamento. A personagem deixa evidente a sua confusão e apego às lembranças, afinal sabe que a morte do gomero representa o fim do seu casamento. O presente e o passado se mesclam na narrativa para fazer emergir a segunda história, o momento singular que ilumina a narrativa: a ruptura do ciclo de união entre Brígida e Luis. A personagem passa então a enxergar o marido de outra forma, como se o véu da ilusão tivesse sido derrubado no mesmo instante que o gomero. A luz representa a verdade que salta aos olhos de Brígida, pois, ao invadir e iluminar o quarto de vestir, permite a ela enxergar o esposo como ele é de fato: velho, enrugado e com as mãos cheias de veias grossas.

No enredo, temos três estações claramente marcadas pelo narrador, assim como as músicas dos três compositores. As composições não só correspondem à determinada estação do ano, mas também marcam as emoções de Brígida. Ao cortarem o gomero, a narrativa volta para o início quando a personagem já está separada. Sobre a circularidade do conto "El Árbol", Le Jollif pontua:

Los tiempos musicales constan de tres partes sincopadas, cada una encabezada por un compositor distinto. Mozart corresponde a la primavera y al recuerdo de la infancia inocente e irreal de Brígida. Beethoven se manifiesta con la primavera y sigue con el verano componiendo la construcción de la relación de Luis. Chopin acompaña la lluvia estival hasta llegar al otoño y a la fragmentación de la pareja ilustrada por el sufrimiento, la resignación y el impulso de huida de Brígida. En "El árbol", la música del compositor Beethoven ocupa un lugar predominante y representa ese acento fuerte de la síncopa que determina de alguna manera el sino trágico de Brígida. (LE JOLLIF, 2013, p.75).

Le Jollif defende que os tempos musicais dos três compositores estão divididos em três partes, acompanhando as três estações que aparecem no conto e embalam as memórias e os sentimentos de Brígida. Estes três momentos, aparentemente divididos, estão atrelados e reforçam a ideia de uma narrativa circular, pois acompanham a personagem até o fim de seu matrimônio, trazendo-a de volta ao início quando ela, já separada, assiste a um concerto de música clássica. 
OLIVEIRA,T.L.;FREIRE,D.J.

\section{As duas Histórias e o Gomero}

Ricardo Piglia (2010), em "Tesis sobre el cuento", afirma que um conto sempre conta duas histórias. Uma delas estaria em um plano superficial, em que se narram os acontecimentos, e a outra estaria em um segundo plano, cuja leitura pode revelar uma história secreta descrita de forma elíptica e fragmentária. Piglia exemplifica sua teoria a partir de uma anedota de Chéjov: um homem vai ao Cassino, ganha um milhão e, ao voltar para casa, se suicida. A partir dessa anedota, o crítico explica que "contra lo previsible y convencional (jugar-perder-suicidarse) la intriga se plantea como una paradoja" (PIGLIA, 2010, p.105), explicando que a anedota, ao tentar desvincular o relato do jogo do suicídio, apresenta a possibilidade de duas histórias que devem emergir em uma mesma narrativa.

No conto "El Árbol", a primeira história, a da superfície, surge a partir do olhar de um narrador onisciente que discorre sobre os acontecimentos, inclusive íntimos, da vida conjugal de Brígida. A história é narrada a partir das lembranças, resgatadas tanto no passado mais distante quanto no recente, com flashes da infância e da adolescência da personagem até chegar à vida adulta, momento da enunciação da narrativa, quando o leitor acompanha as reflexões de Brígida sobre sua separação matrimonial e suas buscas por justificativas que expliquem seu fracasso como esposa e mulher. Brígida é descrita como uma mulher passiva, submissa, e, por vezes, ignorante, que sucumbe ao sistema patriarcal e leva uma vida vazia:

"¡Si tuviera amigas!" - suspiraba ella. Pero todo el mundo se aburría con ella. ¡Si tratara de ser un poco menos tonta! ¿Pero cómo ganar de un tirón tanto terreno perdido? Para ser inteligente hay que empezar desde chica, ¿no es verdad? (BOMBAL, 1996, p.213).

Antes de casar-se, Brígida vivia com as irmãs e o pai, o único responsável pela educação das filhas em razão da morte prematura da mãe. Depois de casada, a referência masculina de autoridade é transferida para o marido, amigo de longa data da família. O pai considera a união como a última esperança para sua filha caçula, sempre preterida pelos homens. Porém, em sua vida conjugal, Brígida não se sente amada por causa da constante ausência de seu marido, sentimento que a leva a questionar o porquê do casamento:

Le sonreía, eso sí, le sonreía con una sonrisa que ella sabía maquinal. La colmaba de caricias de las que él estaba ausente. ¿Por qué se había casado con ella? Para continuar una costumbre, tal vez para estrechar la vieja relación de amistad con su padre. (BOMBAL, 1996, p. 213-214).

O processo de despertar da jovem esposa inicia-se devido à sua insatisfação com o casamento, principalmente por acreditar que Luis aceitou a união por mera formalidade. Brígida não enxerga o amor como o motivo que levou Luis a desposá-la, mas sim uma forma de estreitar a amizade com seu pai. Em seu primeiro ano de casada, o marido quebra a

Revista do SELL, Uberaba/MG (online) - V. 9 n. 2, p. 278-297, jul./dez. - 2020. 
OLIVEIRA,T.L.;FREIRE,D.J.

primeira promessa, que seria a de levá-la à Europa, pois prioriza outras ocupações, como o trabalho, colocando-a sempre em último plano:

(...) La vida de Luis, por lo tanto, consistía en llenar con una ocupación cada minuto del día. ¡Cómo no haberlo comprendido antes! ¡Su padre tenía razón al declararla retardada!

- Me gustaría ver nevar alguna vez, Luis.

- Este verano te llevaré a Europa y como allá es invierno podrás ver nevar.

- Ya sé que es invierno en Europa cuando aquí es verano. ¡Tan ignorante no soy!

$[\ldots]$

Llegó el verano, su primer verano de casada. Nuevas ocupaciones impidieron a Luis ofrecerse el viaje prometido.

- Brígida, el calor va a ser tremendo este verano en Buenos Aires. ¿Por qué no te vas a la estancia con tu padre?

- ¿Sola?

- Yo iría verte todas las semanas, de sábado a lunes.

Ella se había sentado en la cama, dispuesta a insultar. Pero en vano buscó palabras hirientes que gritarle. No sabía nada, nada. Ni siquiera insultar. (BOMBAL, 1996, p. 214).

As memórias da personagem denunciam que o pai a considerava 'retardada', prefigurando, assim, seu rebaixamento intelectual e inferior com relação às irmãs. Ademais, o marido se nega a passar as férias com sua esposa, sugerindo que ela fique com o pai na fazenda, como acontecia quando era solteira. Ou seja, a mudança de estado civil parece ter sido apenas uma forma de dar justificativas à sociedade e não uma união, de fato, entre um homem e uma mulher que se amam e compartilham suas vidas.

Brígida, ao acessar essas lembranças, percebe que o esposo reproduz fortemente as atitudes que o pai tinha com ela, quando a deixava de lado, colocando suas ocupações em primeiro lugar. Ao perceber essa repetição em sua vida, a personagem se lembra do que o pai dizia a seu respeito e percebe a mesma atitude na figura no marido. A similitude entre o tratamento do pai e, depois, do marido faz com que ela tenha uma atitude inesperada, pois, ao invés de aceitar a condição imposta pelo marido, decide usar o silêncio em seu favor para afrontá-lo e mostrar sua insatisfação. O silêncio incomoda Luis de tal forma que ele chega a indagar se a esposa deseja a separação:

Por primera vez él la había llamado desde el club a la hora del almuerzo. Pero ella había rehusado salir al teléfono, esgrimiendo rabiosamente el arma aquella que había encontrado sin pensarlo: el silencio.

(...)

- ¿Es nuevo, Brígida? Contesta, contéstame...

Pero ella tampoco esta vez quebró el silencio.

$Y$ enseguida lo inesperado, lo asombroso, lo absurdo. Luis, que se levanta de su asiento, tira violentamente la servilleta sobre la mesa y se va de la casa dando portazos.

Ella se había levantado a su vez, atónita, temblando de indignación por tanta injusticia. "Y yo, y yo - murmuraba desorientada -, yo que durante casi un año... cuando por primera vez me permito un reproche... ¡Ah, me 
voy esta misma noche! No volveré a pisar nunca más esta casa...". (BOMBAL, 1996, p.215).

O silêncio permite ao leitor espreitar a segunda história, escondida nos interstícios da primeira, ou seja, na superfície do conto, em que se destacam o casamento e a relação familiar de Brígida com seu pai e suas irmãs. Para Piglia (2004, p.108), o efeito surpresa se produz quando a história secreta emerge na superfície da narrativa. No conto "El Árbol", este efeito é produzido pelo silêncio imposto por Brígida a seu marido, fazendo com que ele decida ir embora e a culpe por isso. O leitor sente o efeito surpresa quando a personagem consegue romper com o conformismo do seu casamento por estar cansada de sua rotina e das promessas não cumpridas pelo marido.

A segunda história está permeada pelo silêncio e pela árvore, el gomero ${ }^{4}$, cujo corte ilumina a narrativa. O leitor se depara com a árvore desde o título, ou seja, não há como fugir e não perceber sua pertinência para a construção de sentidos no conto. $O$ primeiro contato entre Brígida e o gomero ocorre quando a personagem, já casada, ao se sentir triste, busca consolo no quarto de vestir. Do lado de fora da casa, próxima à janela deste quarto, está a árvore, imensa e com uma copa frondosa, que propiciava diversas impressões e sensações boas em Brígida. O gomero era a única árvore da estreita rua e atraía todos os pássaros do bairro, proporcionando, com sua sombra, um clima agradável e ameno, que, para Brígida, se traduzia em um misto de paz e conforto espiritual:

Sus despertares ¡Ah, que tristes sus despertares! Pero - era curioso apenas pasaba a su cuarto de vestir, su tristeza se disipaba como por encanto.

Un oleaje bulle, bulle muy lejano, murmura como un mar de hojas. ¿Es Beethoven? No.

Es el árbol pegado a la ventana del cuarto de vestir. Le bastaba entrar para que sintiese circular en ella una gran sensación bienhechora. ¡Qué calor hacía siempre en el dormitorio por las mañanas! ¡Y qué luz cruda! Aquí, en cambio, en el cuarto de vestir, hasta la vista descansaba, se refrescaba. Las cretonas desvaídas, el árbol que desenvolvía sombras como de agua agitada y fría por las paredes, los espejos que doblaban el follaje y se ahuecaban en un bosque infinito y verde. ¡Qué agradable era ese cuarto! Parecía un mundo sumido en un acuario. ¡Cómo parloteaba ese inmenso gomero! Todos los pájaros del barrio venían a refugiarse en él. Era el único árbol de aquella estrecha calle en pendiente que, desde un costado de la ciudad, se despeñaba directamente al río. (BOMBAL, 1996, p. 212-213).

O primeiro contato da personagem com o gomero é descrito de forma mística, pois a árvore tem o poder de transformar o ambiente do quarto de vestir, tornando-o restaurador e benéfico. Nesse espaço, por causa da presença da árvore, Brígida se entrega a uma sensação de plenitude e paz, esquecendo-se de seus dissabores e problemas

\footnotetext{
${ }^{4}$ Essa árvore pertence à família do Fícus, que, segundo o dicionário Houaiss (2013), reúne cerca de 750 espécies, suas raízes costumam ser aéreas e subterrâneas, geralmente poderosas, e suas folhas quase sempre simples.
}

Revista do SELL, Uberaba/MG (online) - V. 9 n. 2, p. 278-297, jul./dez. - 2020. 
OLIVEIRA,T.L.;FREIRE,D.J.

matrimoniais. Assim, quando se sente infeliz na relação conjugal, o gomero acalenta seu sofrimento: "!Que agradable era ese cuarto! Parecía un mundo sumido en un acuario".

Esse tipo de árvore, do gênero Fícus, carrega consigo uma carga simbólica que permite sua relação com diversos significados, pois está presente em distintas culturas. Em Chevalier (2003), as possibilidades de simbologias convergem para um ponto comum: a ideia de Cosmo Vivo em razão da perpétua regeneração. Essa leitura é possível devido à vida cíclica das árvores diante das estações do ano. Apesar de não ser usual considerar essas árvores como sagradas, é comum que se tornem objeto de culto. A árvore também é vista como representação do símbolo da vida, pois, ao crescer em direção aos céus e fincar raízes no subterrâneo, evoca o aspecto da verticalidade, simbolizando as relações entre o céu e a terra (CHEVALIER, 2003, p.84). O desfolhar e a constante renovação de sua copa reafirmam a ideia cíclica da evolução cósmica, ou seja, morte e regeneração. Ao mediar essa conexão entre o céu e a terra, ela se torna o centro dessa relação. Como a presença da árvore e a vida matrimonial de Brígida são centrais na construção da narrativa, a figura do gomero pode representar o casamento, ou seja, é quem sustenta a relação conjugal, mas também determina sua morte e a regeneração da personagem.

Essa leitura encontra eco na simbologia da tradição judaico-cristã em que "a árvore é considerada o pilar central que sustenta o templo ou a casa, e é também a coluna vertebral a sustentar o corpo humano, templo da alma" (CHEVALIER, 2003, p.85). Assim, o gomero sustenta a casa e o casamento de Brígida como templo sagrado. Enquanto a árvore protege o quarto de vestir, Brígida consegue o alento e o abrigo necessários para continuar mantendo seu casamento, ainda que não esteja feliz e satisfeita.

Brígida começa a sentir-se triste em razão das fugas matinais de Luis, que saia silenciosamente com a justificativa de não querer acordá-la, quando, no fundo, queria evitar seus pedidos constantes de carícias e atenção. Nesses momentos, ela recorre ao quarto de vestir para se consolar, pois, neste espaço, encontra a paz em razão da proximidade da árvore. Essa relação de Brígida com o gomero permite ao leitor perceber a interferência da árvore em seus sentimentos e também na relação do casal. Quando Luis decide ir embora por causa do silêncio imposto por Brígida, ela vai ao quarto de vestir, de forma agressiva e indignada, e atira ao chão as roupas do armário, esbravejando e jurando abandonar o esposo. Nesse momento, o inesperado acontece, um estrondo do gomero interrompe seu acesso de fúria:

(...) Y abría con furia los armarios del cuarto de vestir, tiraba desatinadamente la ropa al suelo.

Fue entonces cuando alguien o algo golpeó en los cristales de la ventana.

Había corrido, no supo cómo ni con que insólita valentía, hacia la ventana. La había abierto. Era el árbol, el gomero que un gran soplo de viento agitaba,

Revista do SELL, Uberaba/MG (online) - V. 9 n. 2, p. 278-297, jul./dez. - 2020. 
OLIVEIRA,T.L.;FREIRE,D.J.

el que golpeaba con sus ramas los vidrios, el que la requería desde afuera como para que lo viera retorcerse hecho una impetuosa llamarada negra bajo el cielo encendido de aquella noche de verano. (BOMBAL, 1996, p.216).

De maneira incisiva e abrupta, a árvore interrompe a ira de Brígida com o golpe na janela, assim, de forma personificada, o gomero sustenta o casamento e interfere diretamente na vida do casal. A fim de interromper o ímpeto da personagem em ir embora, a árvore quebra os vidros da janela. É como se o golpe contribuísse para que Brígida desistisse de abandonar o lar durante a noite, fazendo com que ela se concentre na melodia da chuva de verão tocando a folhagem da árvore. O gomero torna-se uma personagem da narrativa com ações que não só inspiram Brígida a aceitar sua condição, mas também a fazem permanecer na mesma situação:

(...) Durante toda la noche oiría crujir y gemir el viejo tronco del gomero contándole de la intemperie, mientras ella se acurrucaría, voluntariosamente friolenta, entre las sábanas del amplio lecho, muy cerca de Luis. (BOMBAL, 1996, p.216).

O casamento sem amor e rotineiro de Brígida e Luis se arrasta após o desentendimento, porém o esposo decide aderir ao silêncio imposto pela mulher. Quando se cansa, pergunta-Ihe se ela não o quer mais. Sua vontade era responder que ainda o queria, mas Luis não espera a resposta e pondera sobre a separação, principalmente como seria considerada pela sociedade, que não a veria com bons olhos.

O comportamento de Luis ao demonstrar que o casamento é mera situação social provoca questionamentos e dúvidas em Brígida sobre essa instituição social. Apesar do desejo de reagir contra as ponderações do esposo, ela percebe que seria inútil se exaltar, ainda que ele gostasse dela com ternura e medida. Se um dia ele chegasse a odiá-la, a odiaria com justiça e prudência, pois assim era a vida. E então, apoiada na janela, ela medita olhando o gomero, que recebia com tranquilidade e regularidade a chuva que o golpeava, essa passividade em receber a chuva serenamente, uma característica humana, reitera a personificação da árvore: Allí estaba el gomero recibiendo serenamente la lluvia que lo golpeaba, tranquilo y regular (BOMBAL, 1996, p.217). Para Brígida, o gomero representa este momento de acomodação aos padrões em sua vida, ou seja, aceitar os golpes que Luis desferiu contra o amor que ela lhe dedicava e esperava retribuição:

(...) Allí estaba el gomero recibiendo serenamente la lluvia que lo golpeaba, tranquilo y regular. El cuarto se inmovilizaba en la penumbra, ordenado y silencioso. Todo parecía detenerse, eterno y muy noble. Eso era la vida. Y había cierta grandeza en aceptarla así, mediocre, como algo definitivo, irremediable. Mientras del fondo de las cosas parecía brotar y subir una melodía de palabras graves y lentas que ella se quedó escuchando, "Siempre", "Nunca"... (BOMBAL, 1996, p. 217). 
OLIVEIRA,T.L.;FREIRE,D.J.

O corte do gomero coincide com o final do casamento de Brígida e Luis. Ao ser questionada sobre a separação, Brígida relaciona o momento com o corte da árvore: "- Pero, Brígida, ¿por qué te vas?, por qué te quedabas? - había preguntado Luis. Ahora habría sabido contestarle: - ¡El árbol, Luis, el árbol! Han derribado el gomero". (BOMBAL, 1996, p. 220). O corte do gomero desperta o leitor para a vida de Brígida, pois a luz que entra no quarto de vestir coincide com a iluminação da narrativa. A personagem passa a enxergar o que a "sombra", bem como a proteção, do gomero não a permitia ver, um casamento de aparências e infeliz, que não Ihe deu frutos. Em todos os momentos em que Brígida tentava reagir, havia o impedimento ou interferência da árvore e a personagem acabava cedendo e aceitando a rotina infeliz.

\section{A memória}

A elaboração do tempo no conto "El Árbol" é fragmentada e não cronológica; por essa razão, há predominância do procedimento flashes para acessar as lembranças de Brígida. Nesses flashes, figuram momentos desde a infância até a ruptura do casamento, sendo a música clássica o elo de Brígida com suas memórias, entrelaçando o passado e o presente. As lembranças da personagem são acessadas de forma involuntária, pois é necessário um dispositivo, nesse caso, a música clássica, para que elas sejam ativadas. $\mathrm{O}$ leitor sabe que Brígida teve contato com esse estilo, tendo, inclusive, estudado piano, mesmo sem êxito. Assim, quando Brígida ouve músicas clássicas, suas lembranças são trazidas para a superfície, fluindo involuntariamente como uma 'memória hábito', em que o passado se conserva ao mesmo tempo em que atua sobre o presente. Segundo Ecléa Bosi:

O passado conserva-se e, além de conservar-se, atua no presente, mas não de forma homogênea. De um lado o corpo guarda esquemas de comportamento de que se vale muitas vezes automaticamente na sua ação sobre as coisas: trata-se de memória hábito, memória dos mecanismos motores. De outro lado, ocorrem lembranças independentes de quaisquer hábitos: lembranças isoladas, singulares, que constituiriam autênticas ressurreições do passado. ${ }^{5}$ (BOSI,1994, p.48).

Os hábitos podem ser considerados como algum vício de comportamento, como, por exemplo, tomar sempre o mesmo café, tocar algum instrumento ou frequentar sempre o mesmo lugar. No caso de Brígida, as situações vividas por ela sempre se repetiam como hábitos, ainda que mudassem as pessoas envolvidas. Na sala de concerto, mesmo sem compreender e sentir as composições como um especialista, o passado vem à tona para Brígida porque as músicas provocam sentimentos já experimentados que a fazem lembrar de momentos vividos tanto na infância quanto na adolescência e na fase adulta. A música

\footnotetext{
${ }^{5}$ Grifo da autora do fragmento.
}

Revista do SELL, Uberaba/MG (online) - V. 9 n. 2, p. 278-297, jul./dez. - 2020. 
OLIVEIRA,T.L.;FREIRE,D.J.

seria, então, um mecanismo-motor, especificamente, a 'memória hábito' a que se refere Bosi, pois evoca mecanicamente algo internalizado.

O passado de Brígida atua em seu tempo presente, pois, à medida que as lembranças são evocadas, a personagem revive suas expectativas de outra perspectiva, questionando como se sente em relação à situação atual e alimentando cada vez mais sua frustração em relação ao matrimônio, marcado pela falta de amor e filhos. Assim, suas memórias determinam seu momento atual (o presente), marcado por sua separação. No fragmento, Brígida, ao relembrar a infância e sua relação com Luis, na época em que ele era apenas amigo íntimo de seu pai, busca entender o motivo pelo qual se casou:

Mozart! Ahora le brinda una escalera de mármol azul por donde ella baja entre una doble fila de lirios de hielo. $Y$ ahora le abre una verja de barrotes con puntas doradas para que ella pueda echarse al cuello de Luis, el amigo íntimo de su padre. Desde muy niña, cuando todos la abandonaban, corría hacia Luis. Él la alzaba y ella le rodeaba el cuello con los brazos, entre risas que eran como pequeños gorjeos y besos que le disparaba aturdidamente sobre los ojos, la frente y el pelo ya entonces canoso (¿es que nunca había sido joven?) como una lluvia desordenada. "Eres un collar - le decía Luis. Eres como un collar de pájaros".

Por eso se había casado con él. Porque al lado de aquel hombre solemne y taciturno no se sentía culpable de ser tal cual era: tonta, juguetona y perezosa. (BOMBAL, 1996, p. 210-211)

Diante dessas lembranças, Brígida pondera e conclui que se casou com Luis porque foi o único que a aceitou da forma como ela era: tonta, brincalhona e preguiçosa. Ao vasculhar essas lembranças, o narrador nos conta detalhadamente várias situações, memórias que não são de momentos únicos ou singulares, mas sim um conjunto de recordações que fluem devido à presença da música e à infelicidade da personagem. Segundo Bosi, "A memória-hábito faz parte de todo o nosso adestramento cultural." (1994, p.49), assim, Brígida passa por esse adestramento, principalmente para que tenha um comportamento passivo de filha submissa, educada para ser esposa e cuidar do lar. Logo, os papéis estão restritos a um sistema patriarcal, cuja repetição corrobora com a ideia de uma narrativa circular com situações repetitivas e habituais.

Bosi especifica a diferença entre a 'imagem-lembrança' e a 'memória-hábito', a primeira é caracterizada por uma lembrança em específico, marcada por um momento singular e, para ser acessada, é necessário que o indivíduo o faça de forma voluntária, ou seja, ele, de vontade própria, vasculha as lembranças na busca de um determinado momento, podendo ter uma data certa. Já a memória-hábito é executada mecanicamente, por ser mais recorrente e estar presente no cotidiano, flui de forma mais espontânea, assim, é composta de um conjunto de memórias com base na percepção do presente:

No outro extremo, a lembrança pura, quando se atualiza na imagemlembrança, traz à tona da consciência um momento único, singular, não

Revista do SELL, Uberaba/MG (online) - V. 9 n. 2, p. 278-297, jul./dez. - 2020. 
repetitivo, irreversível, da vida. Daí, também, o caráter não mecânico, mas evocativo, do seu aparecimento por via da memória. Sonho e poesia são, tantas vezes, feitos dessa matéria que estaria latente nas zonas profundas do psiquismo, a que Bergson não hesitará em dar o nome de "inconsciente". A imagem-lembrança tem data certa: refere-se a uma situação definida, individualizada, ao passo que a memória-hábito já se incorporou às práticas do dia a dia. A memória-hábito parece fazer um só todo com a percepção do presente (BOSI, 1994, p.49).

A partir dessa memória que se torna um hábito, porque também é frequente, Brígida aproxima-se de seu passado como uma escavadora, tentando chegar ao momento único que the explique um casamento sem amor e sem filhos. Como nos adverte Walter Benjamin (1995, p.239), “Quem pretende se aproximar do próprio passado soterrado deve agir como um homem que escava. Antes de tudo, não deve temer voltar sempre ao mesmo fato, espalhá-lo como se espalha a terra", ou seja, voltar sempre ao mesmo fato como se fosse um hábito. Nesse movimento, o narrador, ao vasculhar as memórias de Brígida, separa cuidadosamente cada lembrança como um arqueólogo que escava, limpando o fóssil até deixá-lo como era na sua forma original. Assim, ele faz surgir a segunda história, o momento singular, o que estava subtendido pela presença da árvore no quarto de vestir.

Através desse narrador onisciente, Brígida tem a chance de reviver o próprio passado, relembrar e sentir novamente as sensações e sentimentos que os momentos vividos Ihe causaram em épocas passadas. No entanto, ao reviver tais momentos, já não tem a mesma idade de quando passou verdadeiramente pelas situações. Logo, uma nova perspectiva é formada a respeito das experiências vividas, as impressões são outras e a marcam de outra forma. Isso acontece quando revemos algo pela segunda vez em outra época e conseguimos absorver e perceber detalhes que passaram despercebidos no momento em que aconteceu o fato.

A exploração minuciosa das lembranças faz Brígida entender e romper com o comportamento conformista que sempre lhe foi imposto por ser mulher. O acúmulo de lembranças, ao ser digerido novamente pela personagem, a leva a questionar o porquê da união. O ato de 'escavar' essas camadas de memórias em segundo plano permite encontrar fatos, imagens, que, quando isoladas, são indispensáveis para a compreensão de nossa própria história. Como afirma Benjamin:

(...) Pois "fatos" nada são além de camadas que apenas à exploração mais cuidadosa entregam aquilo que recompensa a escavação. Ou seja, as imagens que, desprendidas de todas as conexões mais primitivas, ficam com preciosidades nos sóbrios aposentos de nosso entendimento tardio, igual a torsos na galeria do colecionador. (1995, p. 239).

A partir das lembranças, a construção da imagem de Brígida desde o início da narrativa é a de uma mulher tola, brincalhona, burra e submissa. Desde a infância, os 


\section{OLIVEIRA,T.L.;FREIRE,D.J.}

momentos narrados perpassam situações que a caracterizam como uma fracassada. Esse fracasso é constatado pela própria personagem quando percebe que está enredada em um casamento sem amor e sem filhos. Benjamin afirma com precisão que uma verdadeira lembrança deve, portanto, ao mesmo tempo, fornecer uma imagem daquele que se lembra. Porém, no caso de Brígida, ela é levada através da música a lembrar o passado, e o narrador é quem discorre sobre suas memórias e constrói a imagem da personagem.

Benjamin reitera que as lembranças são como um bom relatório arqueológico, devendo não apenas indicar camadas das quais se originam seus achados, mas também, antes de tudo, aquelas outras que foram atravessadas anteriormente. Assim, vemos a construção e desconstrução da personagem que, no início da narrativa, era dona de uma personalidade passiva e estática. No final, essa imagem é desconstruída, pois ela consegue surpreender e romper com o casamento, saindo da condição de submissa e seguindo em busca de liberdade e alguma garantia de felicidade.

\section{CONSIDERAÇÕES FINAIS}

Em "O conto espanhol contemporâneo: fragmentos da história", Valéria de Marco (1987, p.95) define o conto como o lugar da história breve, do mundo fragmentado, do contínuo cotidiano. De Marco formula a hipótese de que, nesse gênero, os narradores se aproveitam da estrutura fragmentária do conto como forma de expressar o "homem contemporâneo dilacerado". Esse 'homem' sofre as influências da realidade pós-guerra, da mecanização do trabalho, do consumo desenfreado, da informação e da propaganda, que resultaram em outras maneiras de se narrar uma história.

No conto "El Árbol", a imagem desse homem é representada pela personagem Brígida, que sofre com o sistema patriarcal que the foi imposto desde pequena. Ela representa este ser dilacerado por sucumbir às escolhas impostas pela sociedade e por sua família. Quando se casa, ela aceita as condições de viver uma união sem amor e filhos. Mesmo não sendo da forma como sonhava, ela mantém a união matrimonial até onde suporta, mas quando as lembranças interferem no seu modo de ver a vida, decide interromper esse círculo vicioso e romper com o padrão imposto à mulher.

A escolha em analisar a memória como procedimento ficcional no conto surgiu da proposta em investigar esse narrador, que, como um arqueólogo, revolve o passado de Brígida e faz emergir a segunda história, o momento singular, o qual justifica o presente de sua existência. Apesar de tonta e submissa aos olhos dos homens (pai e do marido), Brígida consegue romper com o sistema que a dilacera como mulher, proporcionando a essa experiência particular um contorno coletivo. Assim, o conto contemporâneo cumpre seu 
OLIVEIRA,T.L.;FREIRE,D.J.

papel ao trazer uma narrativa fragmentada da mulher dilacerada pela sociedade patriarcal do início do século XX, mas que consegue transpor as barreiras que lhe são impostas em diversas situações constrangedoras, que ainda sobrevivem nos dias atuais.

\section{REFERÊNCIAS}

BENJAMIN, W. Escavando e Recordando. IN: Rua de mão única. 5a Ed. São Paulo: Editora Brasiliense, 1995, p.239-240.

BIBLIOTECA NACIONAL (Chile). María Luisa Bombal (1910-1980). Santiago: Memoria Chilena. Disponível em: <http://www.memoriachilena.cl/602/w3-article-3597.html>. Acesso em 27 mai. 2015.

BOMBAL, M. L. El Árbol. IN: Fernández, M. R. (org.). Antología de Cuentos Hispanoamericanos. Santiago de Chile: Editorial Universitaria, 1995, p. 209-220.

BOSI, A. Situação e formas do conto brasileiro contemporâneo. IN: O conto brasileiro contemporâneo. São Paulo: Cultrix, 2004, p. 7-21.

BOSI, E. Memória e Sociedade: Lembranças dos Velhos. São Paulo: Companhia das Letras, 1994.

CHEVALIER, J.; GHEERBRANT, A. Dicionário de Símbolos: Mitos, sonhos, costumes, gestos, formas, figuras, cores, números. $17^{\circ}$ ed. Rio de Janeiro: José Olympio, 2003.

DE MARCO, V. O conto espanhol contemporâneo: Fragmentos da história. Florianópolis: DLLE/UFSC, 1987, n. 3, JAN/DEZ. s/p.

HOUAISS ELETRÔNICO. São Paulo: Editora Objetiva, 2013.

LE JOLIFF, T.C. El vals de enajenación: la alteridad trágica en "El Árbol" de María Luisa Bombal. Revista de Literatura Latinoamericana, Valparaiso, Vol. 42, №. 2, 2013.

PIGLIA, R. Tesis sobre el cuento. IN: Formas breves. Barcelona: Anagrama, 2004, p. 73-86.

POE, E. A. A filosofia da composição 1846. IN: Edgar Allan Poe. A filosofia da composição. Rio de Janeiro: 7 Letras, 2011, p. 20-32.

SANTIAGO, S. Narrador pós moderno. IN: Nas malhas da letra. Rio de Janeiro: Rocco, 2002.

\section{Como citar este artigo (ABNT)}

OLIVEIRA,T.L.;FREIRE,D.J. A memória como procedimento ficcional no conto "El Árbol" De María Luisa Bombal.SELL, Uberaba, MG, v. X, n. X, p. XXX-XXX, 2019. Disponível em: <inserir link de acesso>. Acesso em: inserir dia, mês e ano de acesso. DOI: inserir link do DOI.

Como citar este artigo (APA)

Oliveira,T.L \& Freire, D.J. (2020). A memória como procedimento ficcional no conto "El Árbol" De María Luisa Bombal. SELL, X(X), XXX-XXX. Recuperado em: inserir dia, mês e ano de acesso de inserir link de acesso. DOI: inserir link do DOI. 